\title{
Cost effectiveness of the addition of inhaled corticosteroid in moderately persistent asthmatics treated with daily oral bronchodilator
}

Hadiarto Mangunnegoro

\begin{abstract}
Abstrak
Kortikosteroid hisap merupakan obat yang dibuktikan bermanfaat pada pengobatan jangka panjang penderita asma dalam rangka pengendalian asmanya. Di Indonesia bagian terbesar penderita asma masih menggunakan obat oral, khusısnya golongan bronkodilator. Penelitian ini bertujuan menilai manfaat penambahan kortikosteroid hisap pada penderita asma persisten sedang i ung' diterapi dengan bronkodilator oral dibandingkan dengan kelompok penderita yang serupa yang hanya diobati dengan bronkodilator oral selama 6 bulan. Penelitian dilakukan secara acak prospektif pada penderita asma yang berobat jalan di Klinik Asma RSUP Persahabatan. Empat puluh penderita asma persisten sedang dibagi dalam 2 kelompok yang sama. Salu kelompok hanya mendapat kombinasi teofilin salbutamol tiap hari selama 6 bulan (TS) sedangkan kelompok lain mendapat pengobatan yang sama dengan tambahan kortikosteroid hisap Budesonide (BUD). Biaya yang dikeluarkan penderita selama 6 bulan penelitian baik biana langsung maupun tidak langsung dihitung. Hasil penelitian menunjukkan pemberian kombinasi bronkodilator oral setiap hari selama 6 bulan tidak memberikan perbaikan klinik dan fungsi paru. Sedang penambahan kortikosteroid hisap memberikan perbaikan klinik dan fungsi paru yang sangat bermakna. Sedangkan biaya keseluruhan ternyata sedikit lebih rendah pada kelompok steroid hisap. Kesintulan : pemberian kortikosteroid hisap pada penderita asma persisten sedang memberikan hasil yang jauh lebih baik dari segi klinik maupun fungsi paru dibandingkan bila hanya diobati dengan bronkodilator oral yang diberikan secara teratur setiap hari.
\end{abstract}

\begin{abstract}
Inhaled corticosteroid (ICS) is proved to be a very' effective medication in controlling asthma. However it is not widely usc'd in Indonesian patients due to high cost of the drug for most patients. On the other hand, there are also somewhat reluctant attitude of physicians in prescribing ICS. The purpose of the study was to evaluate the efficacy of regular daily oral bronchodilator in a group of moderately persistent asthmatics compared to the other group treated with the same regimen with the addition of inhaled steroid (BUD) for six month period of treatment. Cost benefit analysis were made between the two groups. In a prospective randomized, controlled study, forty moderately persistent asthmatic patients visiting Asthma Clinic Dept. of Pulmonology Persahahatan Hospital, Jakarta u'ere devided into two groups. The first group (TS) was treated with regular daily divided dose of oral bronchoditator consisted of combination of theophyllin $130 \mathrm{mg}$ and salbutamol $1 \mathrm{mg}$, the second group (BUD) received the the same medication wilh the addition of inhaled budesonide via turbuhaler $400 \mathrm{mcg}$ twice daily. The following parameters were measured to assess cost-effectiveness of therapy: clinical symptoms, nocturnal asthma, symptoms free days, work or schoolday loss, lung function parameter (daily peak flow rate, PFR: force expiratory volume I second, $F E V_{l}$; force vital capacity, $F V C$ ), treatment cost, medication cost, clinic visit cost, emergency visit cost, hospital cost. cost of workday lost or school. The results showed that BUD group were far more superior in clinical benefit in terms of reduction of daily symptoms, reduction of nocturnal asthma, reduction school or work loss, improvement of all lung function purameter, and the most important, the total treatment cost was slightly less than TS group. It is concluded that inhaled corticosteroid in combination with daily oral bronchodilator significantly improved the quality of life in moderately persistent asthmatics compared to daily oral bronchodilator alone, the total treatment cost was even slightly less than the latter.
\end{abstract}

Keywords: moderately persistent asthma, oral bronchodilator, inhaled corticosteroid. bulesonide, cost benefit analysis

Asthma is an inflammatory chronic airway disease with the prevalence and severity appear to be increas-

Department of Pulmonology, Faculty of Mcdicine, University of Indonesia, Jakarta, Indonesia ing. ${ }^{1-4}$ In Australia the prevalence was $2.7 \%$ in 1968 and $19.1 \%$ in 1987 . No exact prevalence data in Indonesia so far, however several individual studies showed the prevalence of the disease ranging from 2 $7 \%$ in children. ${ }^{5}$ Indonesian House Hold Survey 1992 showed that asthma together with chronic bronchitis and emphysema represent the sixth (5\% of all death) 
most frequent cause of death in Indonesian population. ${ }^{6}$

Nowadays, affluent communities are becoming more aware of the large and increasing social cost of asthma, beside the cost of the medicine itself. ${ }^{7}$ Under diagnosis and under treatment remain the most significant factors causing the rise of asthma mortality and morbidity. New concept of asthma management has been introduced in recent years to cope with those problems by providing asthma guidelines through related societies or institutions.

Among the medications recommended by these guidelines, anti-inflammatory drugs, essentially inhaled corticosteroids, are the most important drug for long term treatment in controlling asthma. $8,9,10,11$

We have been using modified guidelines adopted from Global Initiatives of Asthma to suit our social and economic condition, ${ }^{12}$ however the biggest problem lies on the acceptability and affordability of relatively expensive inhaled medications specifically inhhaled corticosteroid. Two main reasons for this are : first, only few patients are covered by health insurance, so they have to pay the cost by themselves; secondly, many still belief that inhaled drug is dangerous and it is only indicated for very severe cases. Our data showed that only $25 \%$ of our asthmatics out patient and less than $40 \%$ asthmatics emergency visits used inhaled asthma drugs and much fewer used inhaled steroids $(6.5 \%)$ including moderate and severe persistent asthmatics. This means that a large number of asthmatics still use oral bronchodilator with or without oral corticosteroids as the mainstay of their treatment either as self medication or as prescribed by their physician. ${ }^{13,14,15}$

Our previous studies showed that inhaled steroid, either beclomethasone dipropionate (BDP) or budesonide (BUD) were very effective in reducing asthma symptoms along with improvement of lung function parameters. ${ }^{16,17}$ However we have never evaluated the effect of daily regular oral bronchodilator without inhaled or oral corticosteroid which was used by most asthmatics and prescribed by a large proportion of doctors as shown by our data.

The purpose of this study were: first, to evaluate the benefit of daily regular oral bronchodilator therapy in moderately persistent asthmatics, second, to compare the effectiveness of the addition of inhaled steroid (budesonide) to oral daily bronchodilator with that of bronchodilator only in moderately persistent asthmatics and third, and the most important objective is to analyse the cost benefit ratio in terms of total direct and indirect cost of treatment in the period of 6 months.

\section{METHODS}

The study was held in Asthma Clinic Persahabatan Hospital Jakarta using randomized clinical approach.

Forty subjects of moderately persistent asthma, attending asthma clinic of Persahabatan Hospital Jakarta were recruited for the study. The inclusion criteria were male and female aged between 16 - 60 years, agree to participate by signing the informed consent paper. Asthma patients other than moderately persistent patient, or suffering from other pulmonary or cardiovascular disease, hypertension, pregnancy, and oral steroid dependency were excluded from this study.

Appropriate anamnesis, spirometry, bronchodilator test, chest X-ray, and ECG were performed to select the subject. Adequate information prior the study was given to ensure that the subjects understand how to fill in the daily report note, drug administration, how to measure the peak flow rate, and how to fill in the form of cost concerning asthma treatment.

The patients were divided into two groups. The first group received oral bronchodilator consisted of theophyllin $130 \mathrm{mg}$ and salbutamol $1 \mathrm{mg}$ in capsule, to be taken three times a day (TS group). The second group was treated with the same oral medication plus budesonide turbuhaler $400 \mathrm{mcg}$ dose twice a day (BUD group). Both group were allowed to use their bronchodilator inhaled medication for mild symptoms. In case of acute exacerbation, short course administration of oral prednisone was given along with other therapy such as nebulized beta- 2 agonist in both group.

The duration of treatment period was 6 months or 24 weeks, and the clinical and lung function monitoring were extended for another 4 weeks to evaluate the clinical and lung function parameter after stopping the treatment.

First forced expiratory volume in 1 second $\left(\mathrm{FEV}_{1}\right)$ was assessed during run-in period, then performed every three months and daily report notes were evaluated every month. 
Pulmonary function tests were done using spirometry Microspiro HI 298 (Chest Corp.) and bronchodilator test was performed before and after 4 puffs of inhaled Salbutamol.

Peak Flow Rate (PFR) using Mini Wright PFR were measured three times every morning and afternoon and only the best value were recorded.

The patients also filled the form for calculating the direct and indirect cost of the asthma treatment.

Assessments were emphasised particularly on clinical improvement and the expenses of treatment. The parameter used to monitor clinical improvement were: peak flow rate, $\mathrm{FEV}_{1}$, force vital capacity (FVC), number of symptom free days, number of nocturnal symptom, loss of working or school days, frequency of exacerbation, severity of disease, frequency of emergency visit, and length of hospital stay.

The expenses were calculated in monthly basis for cost of drugs, transportation cost to the clinic, emergency visits, hospital care, cost of missing workday and cost of missing school day.

Data are expressed as mean \pm standard deviation. Statistical analysis was done using student's test or nonparametric Mann-Whitney U test. A probability value of less than 0.05 was considered as statistically significant.

\section{RESULTS}

There were 40 subjects in the study, 13 males and 27 females, with average age of $35 \pm 9$ years old. The characteristics of the subjects can be seen in table 1 .

Table 1. Age group and sex distribution of the study population

\begin{tabular}{lccr}
\hline \multirow{2}{*}{ Age } & \multicolumn{2}{c}{ S e x } & Total \\
\cline { 2 - 3 } & Male & Female & \\
\hline $16-19$ & - & 6 & 6 \\
$20-24$ & - & - & - \\
$25-29$ & 1 & 3 & 4 \\
$30-34$ & 3 & 4 & 7 \\
$35-39$ & 6 & 5 & 14 \\
$40-44$ & 1 & - & 6 \\
$45-49$ & 1 & 1 & 1 \\
$50-54$ & 1 & 27 & 2 \\
\hline Total & 13 & & 40 \\
\hline
\end{tabular}

In BUD group there was statistically significant $(\mathrm{p}<$ 0.01 ) increase of PFR from $273 \pm 40 \mathrm{~L} / \mathrm{min}$ before to
$371 \pm 56 \mathrm{~L} / \mathrm{min}$ at the end of the study. On the contrary, there was significant $(\mathrm{p}<0.05)$ decrease of PFR in TS group from $281 \pm 58 \mathrm{~L} / \mathrm{min}$ to $272 \pm 59 \mathrm{~L} / \mathrm{min}$. The difference of these two groups was statistically significant as shown in figure 1.

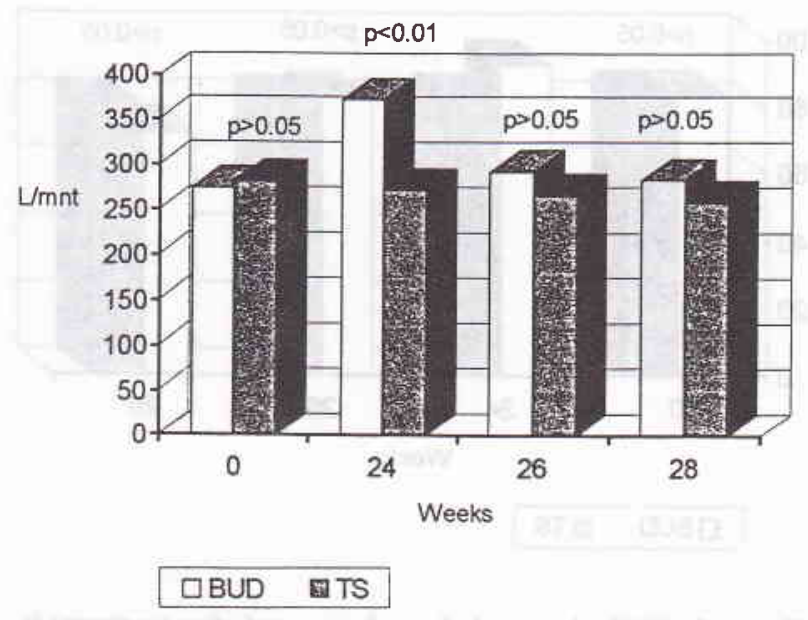

Figure 1. The PFR value before, during and after drug administration in two groups

In BUD group, after 6 months of treatment, FEV 1 significantly increases from $71 \pm 5 \%$ to $82 \pm 12 \%$ (p $<0.01$ ). On the other hand, there was a slight decrease of $\mathrm{FEV}_{1}$ in TS group from $71 \pm 8 \%$ to $67 \pm 9 \%$ (p $>0.05$ ). The difference in $\mathrm{FEV}_{1}$ of these two groups after treatment is statistically significant $(\mathrm{p}<0.01)$ as shown in figure 2 .

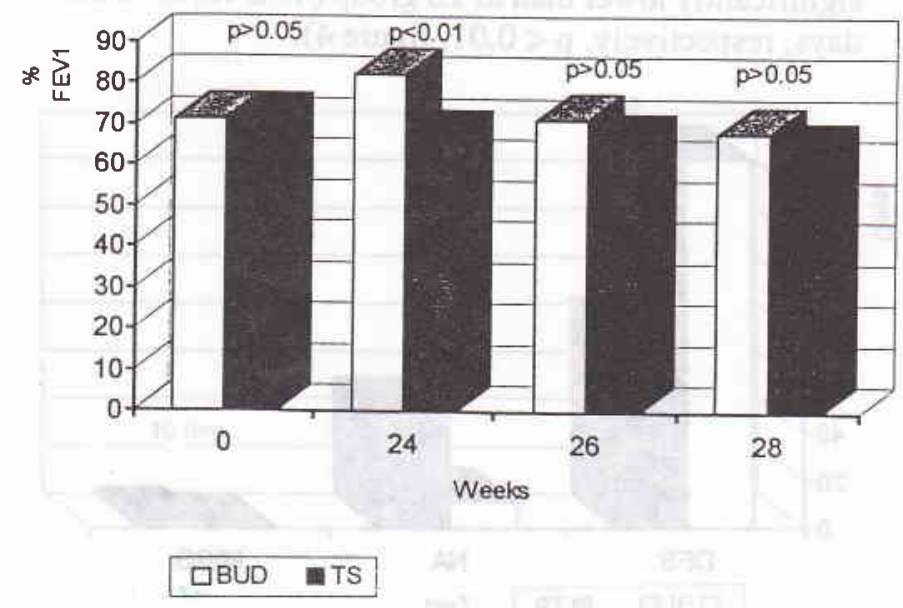

Figure 2. The changes of FEVI before, during and after treatment in the two groups 
FVC in BUD group was $83 \pm 9 \%$ before treatment and $92 \pm 11 \%$ after treatment. This difference is statistically significant $(\mathrm{p}<0.01)$. Whereas in TS group the FVC were $83 \pm 8 \%$ and $82 \pm 11 \%$, respectively before and after treatment (figure 3).

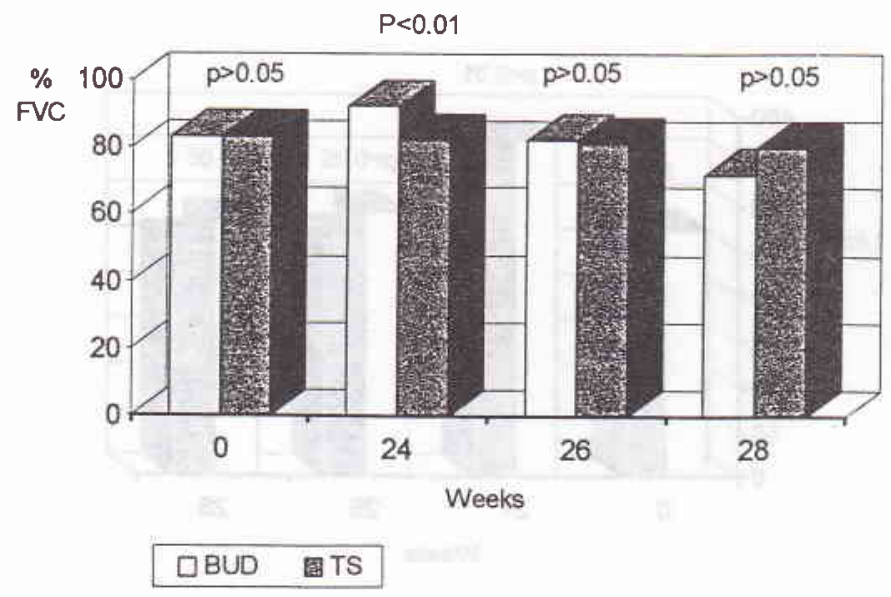

Figure 3. FVC changes before, during and after treatment in the two group

Two weeks and four weeks after the end of treatment, FVC slightly decreased without any significant difference if compared to the value before treatment.

During 6 months of treatment, the number of days with no symptom in BUD group was significantly higher compared to TS group $(155 \pm 24$ versus $83 \pm 54$ days, respectively, $\mathrm{p}<0.01$ ). In contrast, nocturnal asthma and number of absence from school/work in BUD group ( $11 \pm 11 ; 0.2 \pm 0.5$ days, respectively) was significantly lower than in TS group $(49 \pm 42 ; 2.7 \pm 3.1$ days, respectively, $p<0.01$, figure 4 ).

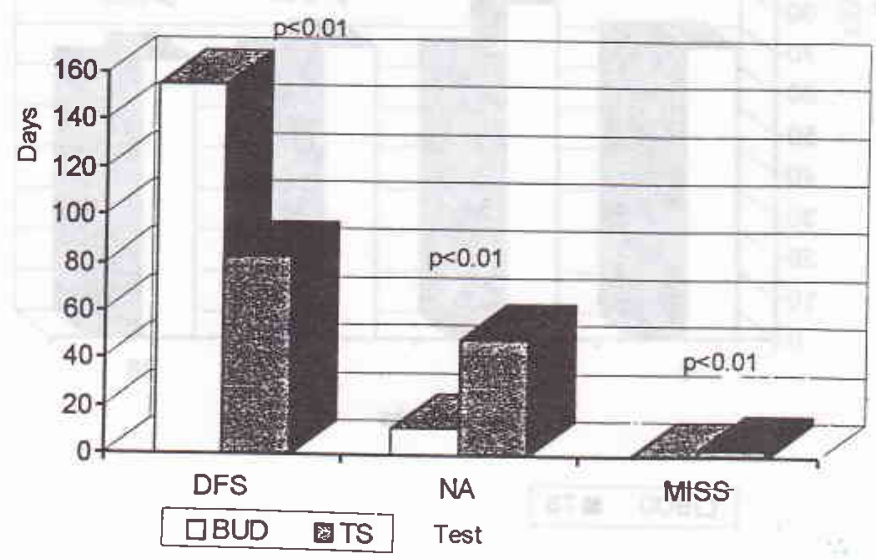

Figure 4. Number of symptom free day (DFS), nocturnal asthma (NA) and days of absence from school or work for all subject (MISS)
The PFR variability in the morning and afternoon of the two groups can be seen in figure 5 .

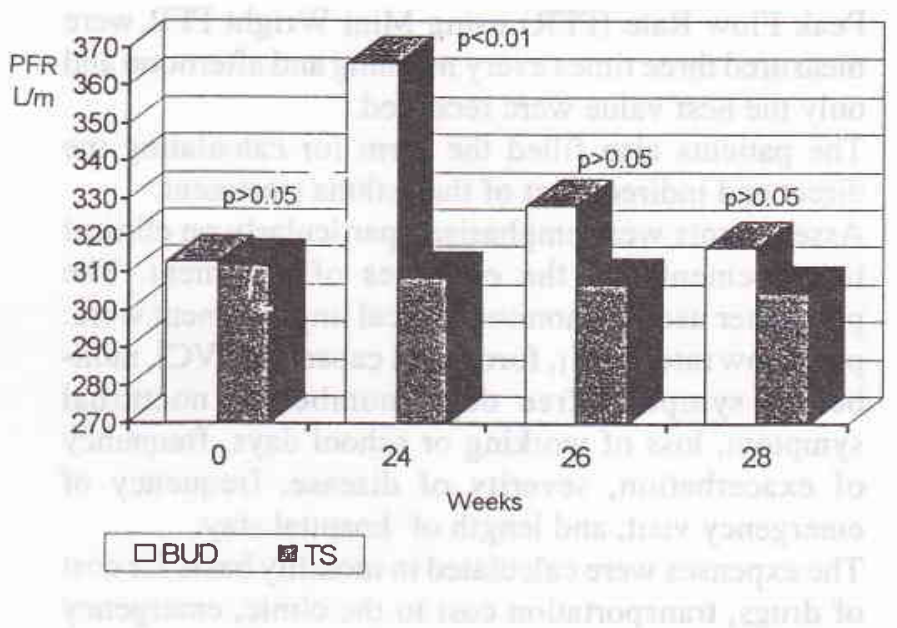

Figure 5. The mean PFR value (morning and afternoon) before, during, 2 weeks and 4 weeks after treatment finish

The use of inhaled beta- 2 agonist after treatment in BUD group reduces but in the TS group increases. However, two and four weeks after the treatment was stopped, the difference of the two groups was not significant (figure 6).

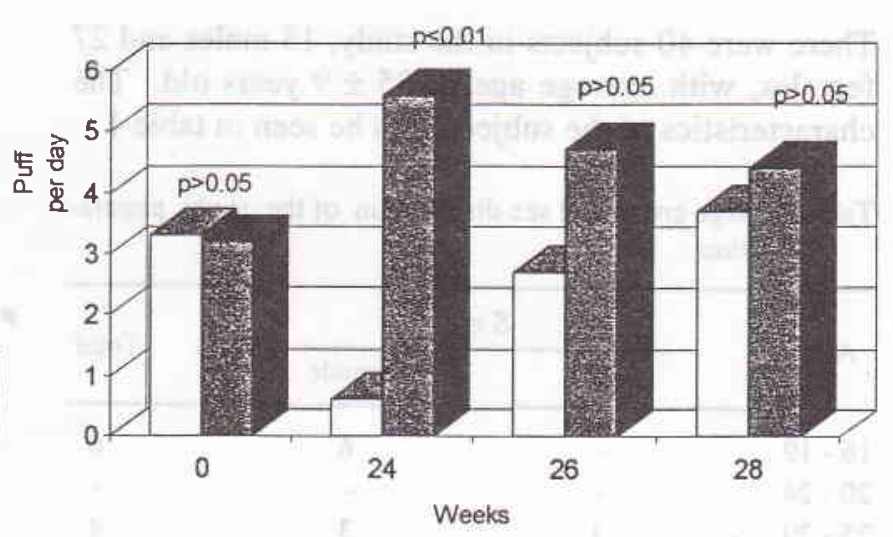

$\square B U D \quad$ 圈 TS

Figure 6. The use of beta-2 agonist inhaler before, during and after treatment

During six months of treatment, the exacerbation of asthma occurred more frequently and more severely in TS group, even in one subject the exacerbation was such severe and need hospitalisation (figure 7). 


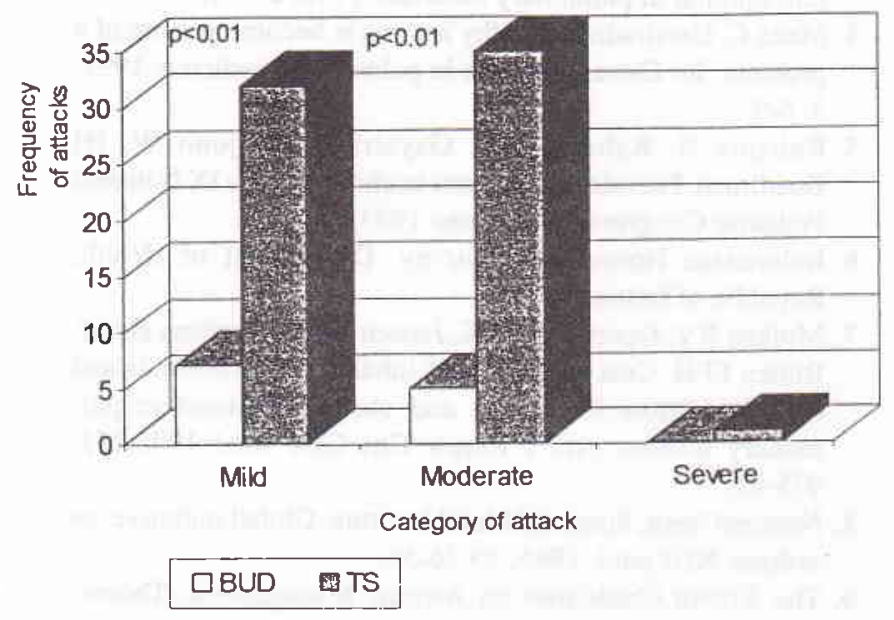

Figure 7. The frequency of exacerbation and severity of attack in both groups

\section{Cost of Asthma (before economic crisis)}

Cost of drug alone in BUD group was Rp 574.200.- per patient while that of control group (TS) was Rp 369.000.- which was 2,8 time more expensive. However BUD group showed reduction of direct cost due to reduced oral steroid, beta- 2 agonis inhalation, antibiotics and cost for clinic or emergency visit at the sum of Rp 322.000,- which was significantly different from that of TS group.

There was Rp 22.000,- which can be saved for every subject in the BUD group in term of total cost due to reduced indirect cost such as absence from school or work. The expenses (before economic crisis) of the two groups in shown in figure 8 .

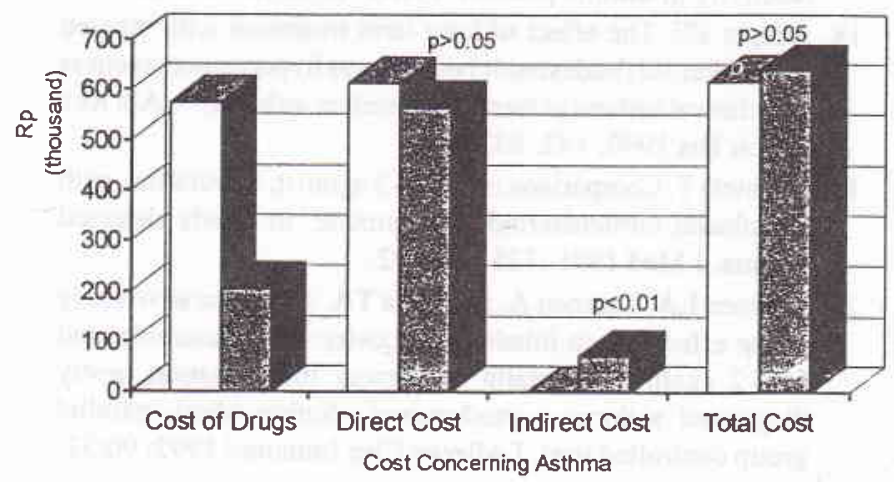

DBUD RTS

Figure 8. Direct and indirect cost concerning asthma in both group

\section{DISCUSSION}

In this clinical trial study, placebo effect can not be seen since double blind method was not applied. The improvement of PFR, FEV 1 , and FVC values after administration of BUD $400 \mathrm{mcg}$ twice daily in this study indicated that BUD can improve the pulmonary function as suggested by Hadiarto et al. ${ }^{16}$ Junifer (1990), proved the same result by administration of BUD $200 \mathrm{mcg}$ twice daily in a longer period (one year), while Haahtela ${ }^{19}$ achieved the increase of FEV 1 with $600 \mathrm{mcg}$ BUD in divided doses in two years. We observed in this study that PFR, FEV 1 and FVC gradually decrease (data not shown) and finally reach before treatment values when BUD is stopped. This finding is in agreement with other studies. ${ }^{16,18}$

In this study, no pulmonary function improvement detected in TS group. This finding showed that administration of only oral bronchodilator such a mixture of theophyllin $130 \mathrm{mg}$ and salbutamol $1 \mathrm{mg}$ could not improve the pulmonary function .

There were more clinical improvements seen in BUD group compared to control group, the same result was also reported by Molken et al. ${ }^{7}$

Recently, there is a rising figure in mortality of asthma, inadequate treatment being the main factor contributing to mortality and morbidity of the disease. ${ }^{19}$ This might be prevented if asthma is detected early and adequately treated with proper anti inflammatory drugs based on the current concept in the pathogenesis of asthma.

Hadiarto and Swidarmoko indicated that the use of inhaled medication in asthma patients is still low (19$29 \%$ ) and much lower for inhaled steroids, while Chairil $^{22}$ gave the figure of $6.5 \%$. The use of inhaled corticosteroid enable the asthma patient to live a near normal life. ${ }^{19,20,21}$

The exacerbation of asthma is more frequent in the TS group rather than in the BUD group. Only one subject of the BUD group was hospitalized. This might be due to strict monitoring to all subjects during the study period, while in daily life many asthma patients cannot recognise the initial symptoms of exacerbation of the disease so that the initial treatment during exacerbation was also neglected. Very often, they come to emergency unit already in severe dyspnea. ${ }^{\text {3 }}$

There was no serious side effect of the BUD treatment in this study particularly in terms of hoarseness and oral thrush or candidiasis. 
Interestingly, after three months of treatment, 18 subjects $(90 \%)$ in BUD group who showed improvement could downgraded to mild persistent asthma. On the contrary, only two subjects changed to mild persistent asthma in TS group, and 4 subjects become worse and should be classified in to severe persistent asthma.

Regarding the cost of treatment, there was no doubt that budesonide turbuhaler cost was considered expensive by the majority of patients, however if the calculation of the treatment includes the cost of hospital outpatient visits, emergencies and hospital admission which was more frequently in the TS group, as well as cost of additional drugs during exacerbation, the amount of cost for 6 months therapy was slightly higher in the TS. However the difference is not statistically significant.

There was $R p 89.000,-$ (US\$ 10) saving achieved for every subject in BUD group. Yet the direct an indirect cost regarding asthma was less due to the fewer exacerbation and emergency unit visit.

\section{CONCLUSIONS}

1. Administration of regular oral bronchodilator therapy for six months failed to improve the clinical symptoms and lung function parameters in moderately persistent asthma patients.

2. The addition of inhaled steroid to the regular oral bronchodilator therapy for six months treatment period in moderately persistent asthma patients showed markedly significant improvement clinically and functionally.

3. The total cost of treatment with the addition of inhaled steroid to oral bronchodilator in this study was slightly less than that of oral bronchodilator alone, while the benefit of a much better quality of life is achieved by inhaled steroid added treatment.

4. The use of inhaled steroid did not show significant side effect in terms of hoarseness and oral thrush.

\section{Acknowledgement}

The author wishes to thank PT ASTRA Indonesia for the support of Pulmicort Turbuhaler and PT Dexa Medica for providing Teosal Capsules.

\section{REFERENCES}

1. Woolcock AJ. Epidemilogy of asthma. Am Rev Respir Dis 1992;146:13589.

2. Sears MR. Epidemiology. In: asthma, basic mechanisms and clinical management. $2^{\text {nd }}$ ed. Barnes PJ, Rodger IW, Thomson NC, editors. Academic Press. 1992. p. 1-19
3. Peat JK. The epidemiology of asthma. Review Article. Current opinion in pulmonary medicine 1996; 2 : 7-15

4. Meza C, Gershwin EM. Why asthma is becoming more of a problem. In: Current opinion in pulmonary medicine. 1997; 3: 6-9

5. Rahajoe N, Rahajoe NN, Gayatri P, Muljono W, HI Boediman. Prevalece of asthma in children. The IX National Pediatric Congress; 13-17 June 1993.

6. Indonesian House Hold Survey. Department of Health, Republic of Indonesia 1992.

7. Molken RV, Doorslaer VAK, Jansen MCC, Kertjens HAM, Rutten FFH. Cost and effect of inhaled corticosteroids and bronchodilators in asthma and chronic obstructive pulmonary disease. Am J Respir Crit Care Med 1995;151: 975-82.

8. National heart, lung, and blood institute. Global initiative for asthma. NIH publ. 1995; 95:36-59.

9. The British Guidelines on Asthma Management. Thorax. 1997; 52(Suppl 1): S1-S21

10. Expert Panel Report II: Guidelines for the diagnosis and management of asthma. National asthma education and prevention program; NIH publ. 1997;91-3642

11. Barnes PJ. Inhaled glucocorticoids for asthma. N Eng J Med $1995 ; 332: 886-75$.

12. Hadiarto M. Diagnosis and management of asthma (1),(2). PARU 1995; 15: (1):62-6. (2):111-9.

13. Siregar CA, Dianiati KS, Hadiarto M. Asthma in emergency unit. J Respir Indon. 1996;16:147-52.

14. Hadiarto M. Keypoints in diagnosis and management of asthma in Indonesia. Paper presented in Japan-Korea Joint Symposium of Allergy an IV West Pacific Symposium of Allergy, Utsunomiya, JAPAN, 1994.

15. Swidarmoko B. Work and productivity profile, treatment cost and knowledge, attitude and behaviour toward the disease of asthma patients. PARU 1994; 14 : 7-16.

16. Hadiarto M, Tamsil S, Faisal Y, Heruwiyono W. Efforts to reduce bronchial hyperreactivity in asthmatics. A comparative study between budesonide and ketotifen. PARU 1992; 12: 10-18.

17. Mukhtar I, Faisal Y, Hadiarto M. The effect of beclomethason dipropionate dan ketotifen on bronchial hyperreactivity in asthma patients. PARU 1995;15 : 146-55.

18. Juniper EF. The effect of long term treatment with inhaled corticosteroid (budesonide) on airways hyperresponsiveness and clinical asthma in steroid dependent asthmatics. Am Rev Respir Dis 1990; 142: 832-6.

19. Haahtela T. Comparison of a beta- 2 agonist, terbutaline, with an inhaled corticosteroid, Budesonide, in newly detected asthma. J Med $1991 ; 325$ : 388-92.

20. Laitinen LA, Laitinen A, Haahtela TA. A comparative study of the effects of an inhaled corticosteroid, budesonide, and beta- 2 agonist, terbutalin on airway inflammation newly diagnosed asthma: a randomised, double blind, parallel group controlled trial. J Allergy Clin Immunol 1992; 90:3242.

21. Kerljens HA, Brand PL, Hughes MD, Robinson NJ, Postma DS. A comparison of bronchodilator therapy with or without inhaled corticosteroid therapy for obstructive airways disease. N Eng J Med 1992;237:1413-9. 